\title{
The results of studying the EMF emergence in friction pairs of power machines
}

\author{
Ilmas Salakhutdinov ${ }^{1}$, Denis Molochnikov ${ }^{1 *}$, Andrei Glushchenko², Albert Khusainov $^{2}$, and \\ Ilnar Gayaziev ${ }^{3}$ \\ ${ }^{1}$ Federal State Budgetary Educational Institution of Higher Education «Ulyanovsk State Agrarian \\ University named after P.A. Stolypin», 1, boulevard Novy Venets, 432017, Ulyanovsk, Russia \\ ${ }^{2}$ Ulyanovsk State University, 42, Leo Tolstoy St., 432017, Ulyanovsk, Russia \\ ${ }^{3}$ Federal State Budgetary Educational Institution of Higher Education «Kazan State Agrarian \\ University», St. Karla Marksa, 65, Republic of Tatarstan, 420015, Kazan, Ruassia
}

\begin{abstract}
The work is devoted to the experimental studies of determining the magnitude of the electromotive force (EMF) that arises in the friction pairs of an internal combustion engine (ICE) and the possibility to assess its technical condition by the magnitude of the electromotive force. A research procedure was designed to carry out an experiment. The measurement of small value voltages was carried out using a control and measuring device, the principle of operation of which is based on operational amplifiers (OA). Based on the previously obtained theoretical values of the EMF, the designed millivoltmeter can make measurements in the range of the following values: from $50 \mu \mathrm{V}$ to $1 \mathrm{mV}$ and from $1 \mathrm{mV}$ to $40 \mathrm{mV}$. To ensure the reliability of the readings of the measuring device, its calibration was carried out with the use of an AMPROBE 37XR-A digital multimeter. As a result of the measurements, the relationship between the EMF value and the crankshaft speed of the power plant was established. The analysis of the research results confirms the possibility of diagnostic assessment of the power machine condition by the values of the measured EMF using the proposed measuring complex.
\end{abstract}

\section{Introduction}

During the operation of power machines of cars and tractors, one of the factors causing a decrease in the resource and work efficiency is a change in the parameters of the rubbing surfaces of units and coupled parts up to the peak value.

The change in the geometric parameters of the contacting surfaces and the physicochemical properties of the materials from which they are made occurs for many reasons. One of the essential reasons is the process of crushing and the subsequent separation of the upper metal layer from the surface under the influence of compressive forces and the relative speeds of movement of one surface relative to the other. This process is known as wear. It is known that all types of wear can be conditionally divided into three large groups. The first one is mechanical wear, this is a change in surface parameters only

\footnotetext{
*Corresponding author: denmol@yandex.ru
} 
as a result of the mechanical action of one surface on the other. The second one is wear, which has a corrosion-mechanical nature - when the destruction and separation of metal particles occurs under the influence of not only mechanical action, but also due to concomitant chemical and electrochemical and electrophysical processes. The third group includes the least studied process of wear under the influence of electric currents of various magnitudes arising from the friction of various units and rubbing parts in the machine.

Moreover, if the first two groups have been studied in detail, then wear due to the occurrence of an electric current, i.e. the emergence of the EMF in friction units is still a controversial issue. It should be noted that electroerosive wear is also the reason for the occurrence of current between the contact zones of rubbing pairs.

It is also known that electric current, affecting the metals of internal combustion engine parts, causes a change in their physical properties. Accordingly, this will entail a change in the antiwear properties of materials, and, affect the service life of not only individual friction pairs, but the entire engine as a whole [1-3].

\section{Materials and methods}

The objective of laboratory studies was to measure the electromotive force (EMF) in friction pairs. To carry out measurements in experimental studies, a control and measuring complex was designed that consisted of both commercially produced measuring instruments and specially designed ones taking into account the specifics of the measurements being carried out.

To conduct laboratory studies of the EMF magnitude arising in friction pairs of a power plant during its operation at various temperature and speed conditions, a KI-5543 brake test bench was used with a commercially available UMZ-417 engine installed on it [4-7]. The engine block head was dismantled to measure the EMF values and for the purpose of connecting measuring equipment in the friction unit- the cylinder liner - piston (Fig. 1).
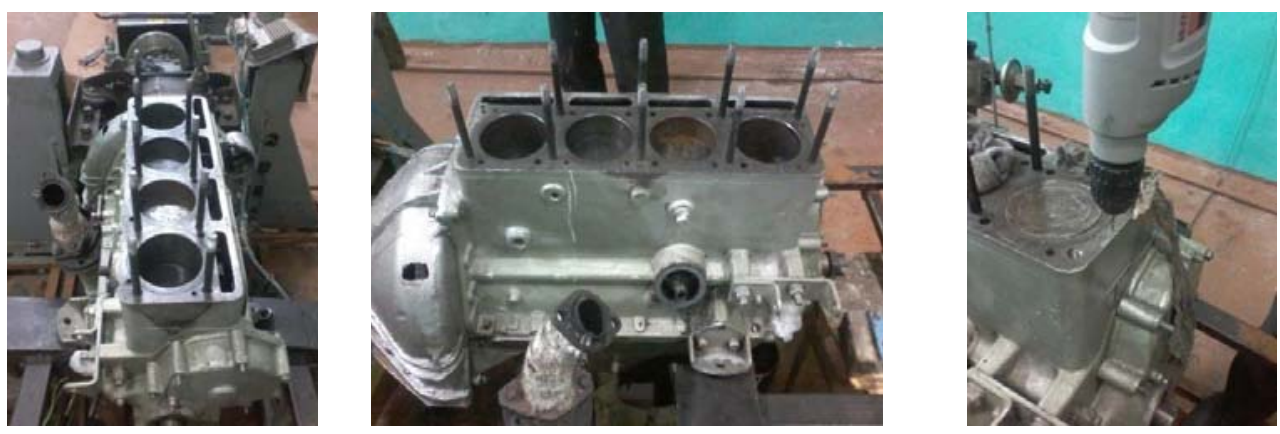

Fig. 1. Type of the engine under study mounted on the brake test bench to determine the EMF that arises in it.

The test model of the power machine includes the sources of the EMF of all its friction pairs formed by different metals. Accordingly, the EMF magnitude in each of the pairs should be different. It was theoretically established that this value is insignificant; therefore, commercially produced measuring instruments cannot be used in the study [8,9]. Because of this, measurements of small voltages were carried out using a control and measuring device, the principle of which is based on operational amplifiers (OA). For this purpose, a millivoltmeter was designed and manufactured (Fig. 2 a, b). In order to determine the reliability of the readings of the designed millivoltmeter, it was calibrated using the AMPROBE 37XR-A commercially available multimeter (Fig. 2 c). 


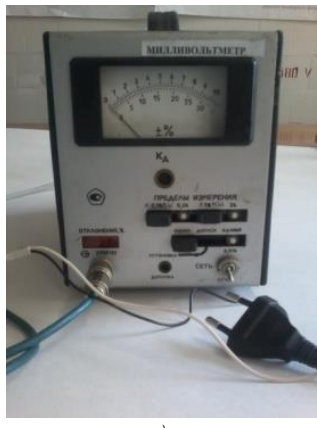

a)

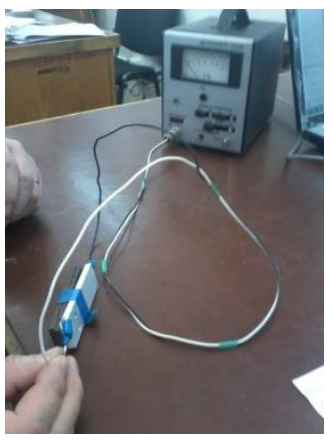

b)

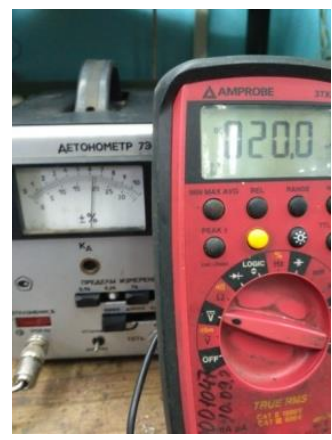

c)

Fig. 2. Type of the proposed millivoltmeter: a, b - general view of the millivoltmeter; $\mathrm{c}$ - the process of calibration of the proposed millivoltmeter.

Due to the small values of the measured voltage, the device provides a non-inverting amplifier based on operational amplifiers (OA) (Fig. 3). With this arrangement, the input signal from the engine goes to the non-inverting input of the OA, and the negative feedback voltage, to calculate the real value of the measured value, is fed to the input of the output voltage divider, through the resistors $\mathrm{R} 1$ and $\mathrm{R} 2$.

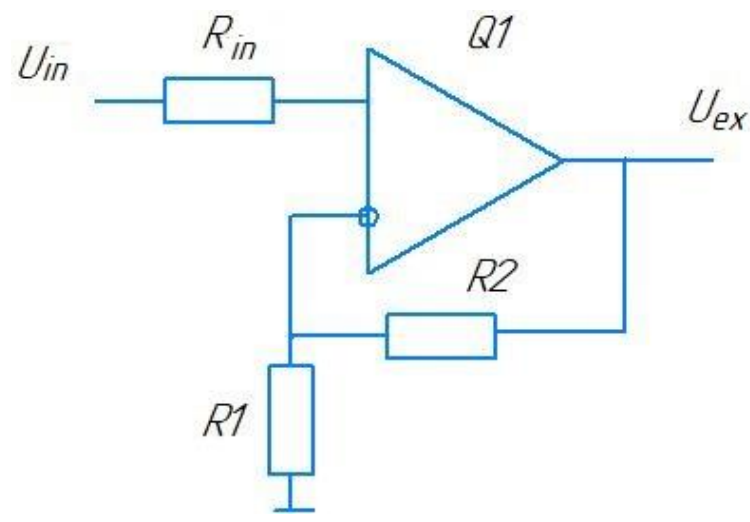

Fig. 3. Scheme of the proposed amplifier of a non-inverting type.

In this case, assuming the ideal OA value, the voltage gain of the proposed noninverting amplifier can be expressed as:

$$
\mathrm{K}=1+\mathrm{R} 2 / \mathrm{R} 1
$$

In this case, with an input voltage of up to $40 \mathrm{mV}$, the amplification coefficient of the $\mathrm{OA}$ will be determined by the deviation of the microammeter pointer to the maximum value provided by the instrument's measurement scale.

Based on these assumptions, a millivoltmeter circuit was developed (Fig. 4). The developed millivoltmeter is two-range, that is, it provides voltage measurements in two ranges: from $50 \mu \mathrm{V}$ to $1 \mathrm{mV}$ and from $1 \mathrm{mV}$ to $40 \mathrm{mV}$.

In the proposed scheme, the device is switched on by moving the "S1" switch to the "ON" position. The action is performed with the switch "S2" to change the designed device to one of the supposed measurement ranges. 

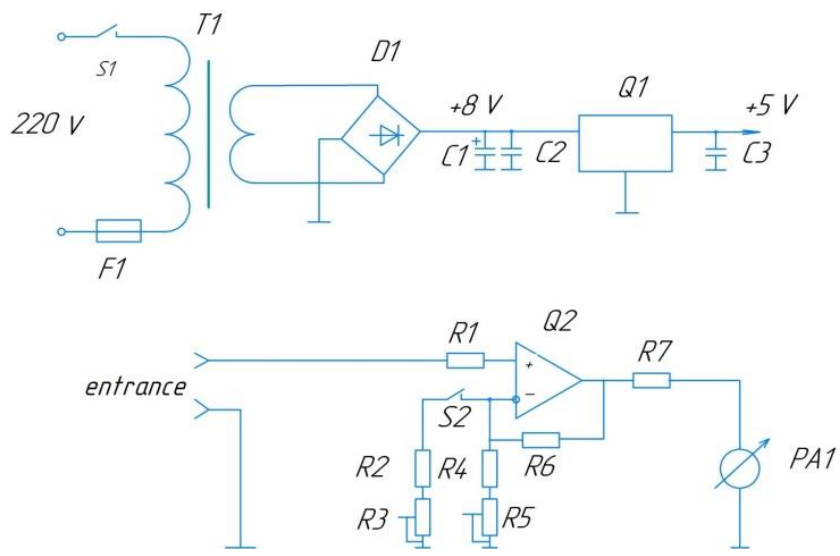

Fig. 4. Scheme of the developed millivoltmeter.

The millivoltmeter, with the proposed electrical measurement scheme, allows the measurement of EMF values not only in the entire engine, but also in its individual friction units. In the course of laboratory studies, we also used multimeters of the Fluke and V1net brands to establish the reliability and repeatability of the measurement results. The conformity of the measured value was checked with the help of the used model ISDS205B oscilloscope "INSTRUSTAR" (Fig. 5 a)

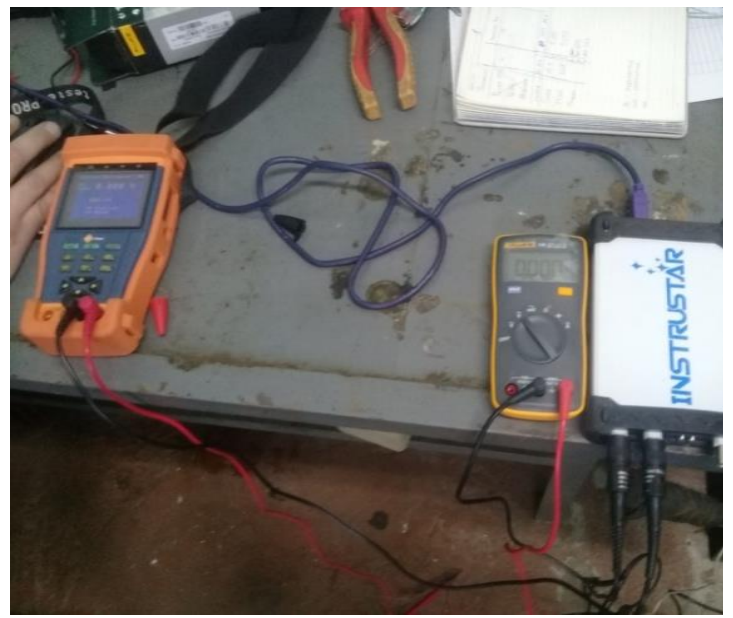

a) oscilloscope / multivoltmeter

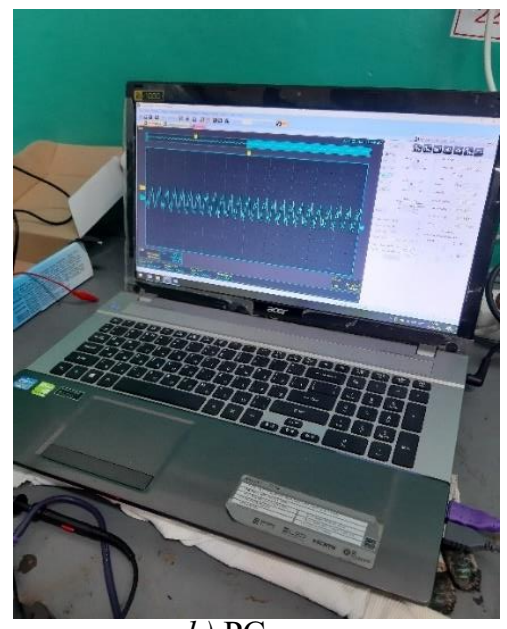

b) $\mathrm{PC}$

Fig. 5. Experimental control measuring complex.

The designed control and measuring complex gives an opportunity to read the values of the EMF which arises in friction pairs under various conditions of load-speed and time modes of engine operation.

The studies were carried out in the following sequence:

1. Assembly and connection of the proposed measuring complex with the studied engine is carried out as follows: the current collector is installed on the engine crankshaft, the output contact of the current collector is connected to the designed measuring complex.

2. Connection to the measurement chain and to the power supply of the control oscilloscope.

3. Installation of the current collector on the engine crankshaft and connection. 
4. Connection of the USB cable (from the digital oscilloscope to the personal computer).

5. Turning on the brake test bench and increasing the crankshaft rotation speed of the engine to $800 \mathrm{~min}^{-1}$.

6. Using the software "USB Oscillograph, reading and recording the values of the EMF magnitude and sensor signals.

7. Using the test bench, increasing the engine crankshaft rotation speed to $1500 \mathrm{~min}^{-1}$.

8. Using the software "USB Oscillograph, reading and recording the values of the EMF magnitude and sensor signals.

Processing the test results and their presentation in tables.

The objective of the bench studies was to determine the EMF in the engine friction pairs, taking into account the changing technical condition of the internal combustion engine and the load-speed mode of operation of its parts.

To establish the magnitude of the emerging EMF, depending on the technical condition of the units and parts of the engine, a KI-5543 GOSNITI brake test bench was used with an UMZ-417 gasoline engine mounted on it (Fig. 6) equipped with a brake weighing device, a tachometer for determining the speed of the engine crankshaft and a specially designed measuring complex (Fig. 7).

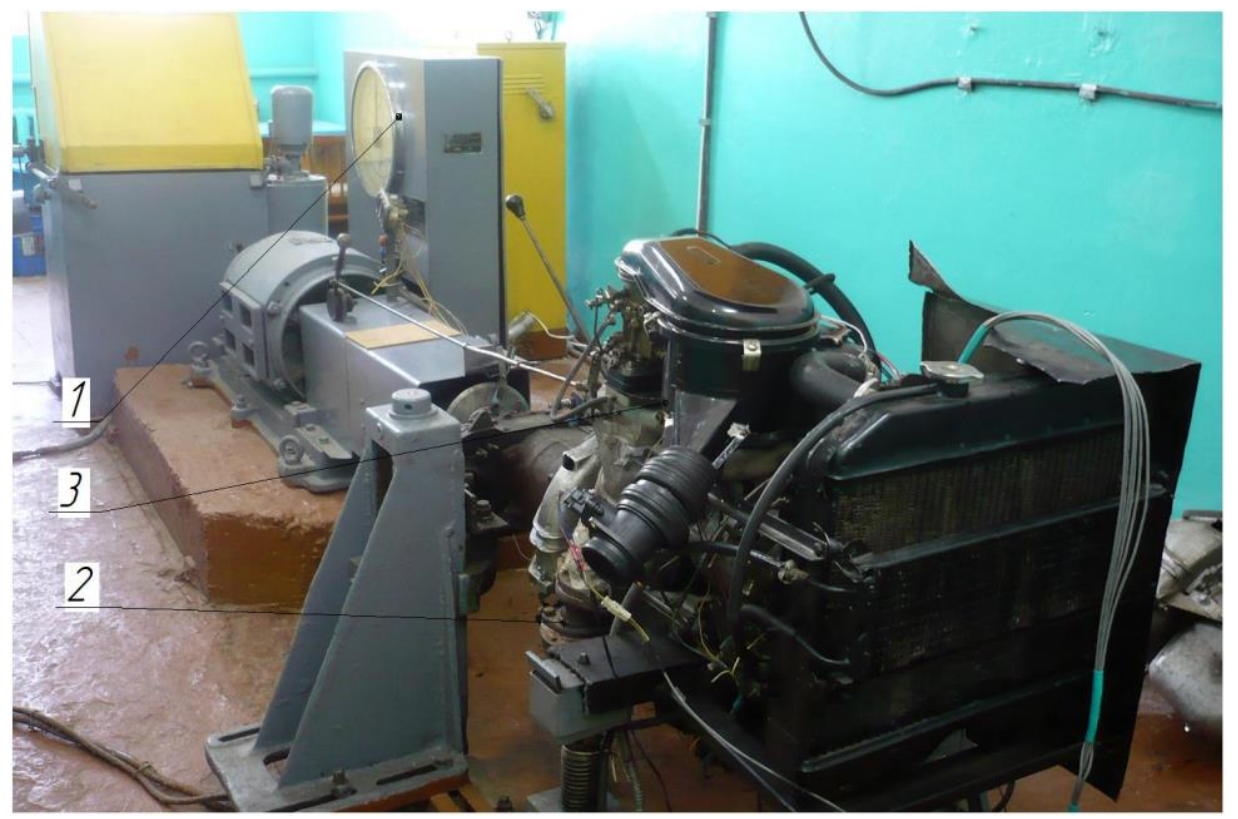

Fig. 6. Bench engine unit 1 - brake tester KI-5543; 2 - exhaust fume removal system; 3 - UMZ-417. 


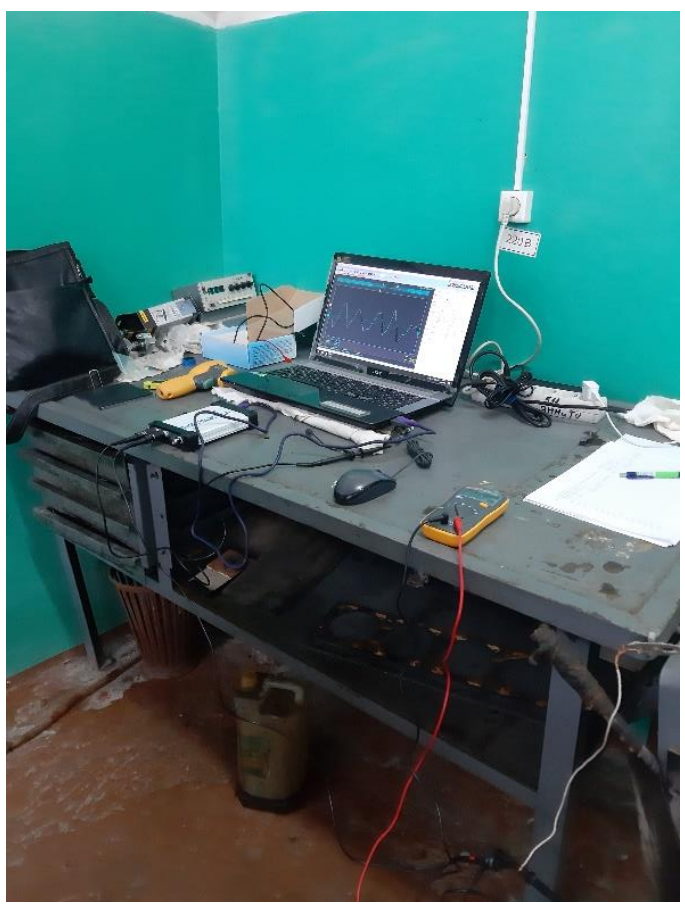

Fig. 7. Measuring complex for determining the EMF magnitude in friction pairs of internal combustion engines.

To determine the total value of the EMF magnitude, depending on the technical condition of the internal combustion engine, studies were carried out on two UMZ-417 engines with different technical conditions.

Before conducting bench studies to determine the technical condition of the UMZ-417 engine by the magnitude of the total EMF, micrometry of friction pairs was carried out. Measurement of the clearance size in the crankshaft couplings was carried out - main journals - inserts of main journals, connecting rod journals - inserts of connecting rod journals; piston - cylinder liner.

The UMZ-417 engines were prepared in accordance with the following requirements. After carrying out micrometer measurements and assembly, the engines were run-in for 3 hours. Then the lubrication system was drained and the engines were filled with $\mathrm{M}-6 \mathrm{z}-12 \mathrm{G}_{1}$ oil recommended by the manufacturer. The EMF readings on both engines were recorded under identical conditions: the crankshaft speed is 800 and $1500 \mathrm{~min}^{-1}$, the temperature values of the environment and crankcase oil: $\mathrm{Tm}=18^{\circ} \mathrm{C}, \mathrm{Tm}=20^{\circ} \mathrm{C}$. Before conducting the tests, the heads of the cylinder blocks were removed from the engines to form a chain of the cylinder liner - the engine block - the current collector (Fig. 8 a). The current collector was installed on the crank nose (Fig. 8 b) [10]. 


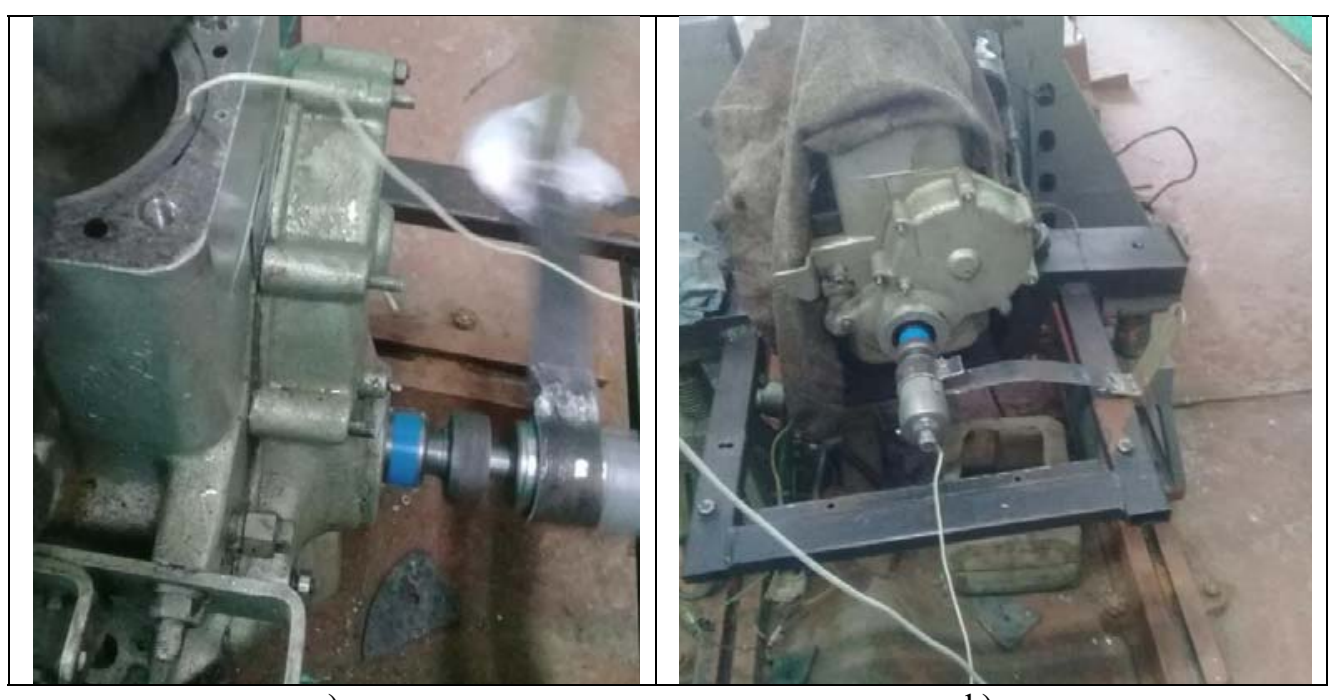

a)

b)

Fig. 8. Bench tests of the UMZ-417 engine: a - connection of the chain cylinder liner - current collector; $b$ - the current collector installed.

\section{Results and their discussion}

The studies were carried out in various operating modes of engines in the fourth gear of transmission. Two instruments Fluke and V1net were used for the reliability of the measurements. The data of the studies carried out are presented in the form of tables for individual lines of measurements of engine friction units.

Table 1. Experimental values of EMF in the measurement chain "piston - cylinder liner - engine block - crankshaft - current collector" (4th gear).

\begin{tabular}{|c|c|c|c|c|}
\hline \multirow{2}{*}{ Device } & $\begin{array}{c}\text { Crankshaft } \\
\text { rotation speed, } \\
\text { min }^{-1}\end{array}$ & $\begin{array}{c}\text { Time of the } \\
\text { experiment, sec. }\end{array}$ & $\begin{array}{c}\text { Crankshaft } \\
\text { rotation speed, } \\
\text { min-1 }\end{array}$ & $\begin{array}{c}\text { Time of the } \\
\text { experiment, sec. }\end{array}$ \\
\cline { 2 - 5 } & 800 & 38 & 1500 & 37 \\
\hline Fluke & $\mathrm{mV} \approx$ & $\mathrm{mV}=$ & $\mathrm{mV} \approx$ & $\mathrm{mV}=$ \\
\hline V1net & 382 & 76 & 343 & 79 \\
\hline
\end{tabular}

Table 2. Experimental values of the EMF in the measurement chain "engine block - crankshaft current collector" (4th gear).

\begin{tabular}{|c|c|c|c|c|}
\hline \multirow{2}{*}{ Device } & $\begin{array}{c}\text { Crankshaft } \\
\text { rotation speed, } \\
\text { min }^{-1}\end{array}$ & $\begin{array}{c}\text { Time of the } \\
\text { experiment, sec. }\end{array}$ & $\begin{array}{c}\text { Crankshaft } \\
\text { rotation speed, } \\
\text { min-1 }\end{array}$ & $\begin{array}{c}\text { Time of the } \\
\text { experiment, sec. }\end{array}$ \\
\cline { 2 - 5 } & 800 & 39,5 & 1500 & 41,5 \\
\hline Fluke & $\mathrm{mV} \approx$ & $\mathrm{mV}=$ & $\mathrm{mV} \approx$ & $\mathrm{mV}=-$ \\
\hline V1net & 306 & 82 & 284 & 91 \\
\hline
\end{tabular}


Table 3. Experimental values of the EMF in the measurement chain "crankshaft - current collector" (4th gear).

\begin{tabular}{|c|c|c|c|c|}
\hline \multirow{2}{*}{ Device } & $\begin{array}{c}\text { Crankshaft } \\
\text { rotation speed, } \\
\text { min }^{-1}\end{array}$ & $\begin{array}{c}\text { Time of the } \\
\text { experiment, sec. }\end{array}$ & $\begin{array}{c}\text { Crankshaft } \\
\text { rotation speed, } \\
\text { min-1 }\end{array}$ & $\begin{array}{c}\text { Time of the } \\
\text { experiment, sec. }\end{array}$ \\
\cline { 2 - 5 } & 800 & 62 & 1500 & 66 \\
\hline Fluke & $\mathrm{mV} \approx$ & $\mathrm{mV}=$ & $\mathrm{mV} \approx$ & $\mathrm{mV}=$ \\
\hline V1net & 202 & 62 & 196 & 66 \\
\hline
\end{tabular}

Using the data obtained on the general measurement chains of the engine, including a closed loop "piston - cylinder liner - engine block - crankshaft - current collector (CC)", as well as using the rule used in electrical circuits, summing up EMF values, we will determine the EMF values by separate friction units of the engine (table 4).

Table 4. Experimental values of the EMF of the chain by engine friction units.

\begin{tabular}{|c|c|c|c|c|c|}
\hline \multirow{2}{*}{ Device } & \multirow{2}{*}{$\begin{array}{c}\text { Crankshaft } \\
\text { rotation speed, } \\
\text { min-1 }\end{array}$} & $\begin{array}{c}\text { Piston - } \\
\text { cylinder liner }\end{array}$ & $\begin{array}{c}\text { Cylinder liner } \\
\text { - engine block }\end{array}$ & $\begin{array}{c}\text { Engine block - } \\
\text { crankshaft }\end{array}$ & \begin{tabular}{c} 
Total value \\
of the \\
EMF, $\mathrm{mV}$ \\
\cline { 3 - 5 }
\end{tabular} \\
\cline { 3 - 5 } & \multicolumn{3}{|c|}{ EMF values, mV $\approx$} \\
\hline \multirow{2}{*}{ Fluke } & 800 & 76 & 104 & 202 & 382 \\
\cline { 2 - 5 } & 1500 & 59 & 88 & 196 & 343 \\
\hline \multirow{2}{*}{ V1net } & 800 & 79 & 106 & 200 & 385 \\
\cline { 2 - 5 } & 1500 & 37 & 90 & 190 & 317 \\
\hline
\end{tabular}

Table 5. Experimental values of EMF in the measurement chain "piston - cylinder liner - engine block - crankshaft - current collector" (4th gear control measurement).

\begin{tabular}{|c|c|c|c|c|}
\hline \multirow{2}{*}{ Device } & $\begin{array}{c}\text { Crankshaft } \\
\text { rotation speed, } \\
\mathrm{min}^{-1}\end{array}$ & $\begin{array}{c}\text { Time of the } \\
\text { experiment, sec. }\end{array}$ & $\begin{array}{c}\text { Crankshaft } \\
\text { rotation speed, } \\
\text { min }^{-1}\end{array}$ & $\begin{array}{c}\text { Time of the } \\
\text { experiment, sec. }\end{array}$ \\
\cline { 2 - 5 } & 800 & 45 & 1500 & 48 \\
\hline Fluke & $\mathrm{mV} \approx$ & $\mathrm{mV}=$ & $\mathrm{mV} \approx$ & $\mathrm{mV}=$ \\
\hline V1net & 392 & 97 & 225 & 57 \\
\hline
\end{tabular}

Table 6. Experimental values of EMF in the measurement chain "engine block - crankshaft - current collector" (4th gear control measurement).

\begin{tabular}{|c|c|c|c|c|}
\hline \multirow{3}{*}{ Device } & $\begin{array}{c}\text { Crankshaft } \\
\text { rotation speed, } \\
\text { min }^{-1}\end{array}$ & $\begin{array}{c}\text { Time of the } \\
\text { experiment, sec. }\end{array}$ & $\begin{array}{c}\text { Crankshaft } \\
\text { rotation speed, } \\
\text { min-1 }\end{array}$ & $\begin{array}{c}\text { Time of the } \\
\text { experiment, sec. }\end{array}$ \\
\cline { 2 - 5 } & 800 & 40 & 1500 & 42 \\
\hline Fluke & $\mathrm{mV} \approx$ & $\mathrm{mV}=$ & $\mathrm{mV} \approx$ & $\mathrm{mV}=$ \\
\hline V1net & 305 & 102 & 205 & 117 \\
\hline
\end{tabular}

Table 7. Experimental values of EMF in the measurement chain "crankshaft - current collector" (4th gear control measurement).

\begin{tabular}{|c|c|c|c|c|}
\hline \multirow{3}{*}{ Device } & $\begin{array}{c}\text { Crankshaft } \\
\text { rotation speed, } \\
\mathrm{min}^{-1}\end{array}$ & $\begin{array}{c}\text { Time of the } \\
\text { experiment, sec. }\end{array}$ & $\begin{array}{c}\text { Crankshaft } \\
\text { rotation speed, } \\
\text { min }^{-1}\end{array}$ & $\begin{array}{c}\text { Time of the } \\
\text { experiment, sec. }\end{array}$ \\
\cline { 2 - 5 } & 800 & 38 & 1500 & 38 \\
\hline Fluke & $\mathrm{mV} \approx$ & $\mathrm{mV}=$ & $\mathrm{mV} \approx$ & $\mathrm{mV}=$ \\
\hline V1net & 238 & 61 & 193 & 58 \\
\hline
\end{tabular}


According to the values of the obtained experimental values, using the rule used in electrical circuits, adding the EMF values, we calculate the EMF value for the engine friction units (Table 8).

Table 8. Experimental values of EMF by engine friction units.

\begin{tabular}{|c|c|c|c|c|c|}
\hline \multirow{3}{*}{ Device } & \multirow{3}{*}{$\begin{array}{l}\text { Crankshaft } \\
\text { rotation speed, } \\
\min ^{-1}\end{array}$} & \multicolumn{3}{|c|}{ Measured chain } & \multirow{3}{*}{$\begin{array}{c}\text { Total } \\
\text { value of } \\
\text { the EMF, } \\
\mathrm{mV} \approx\end{array}$} \\
\hline & & $\begin{array}{c}\text { Piston - } \\
\text { cylinder liner }\end{array}$ & $\begin{array}{l}\text { Cylinder liner } \\
\text { - engine block }\end{array}$ & $\begin{array}{c}\text { Engine block - } \\
\text { crankshaft }\end{array}$ & \\
\hline & & \multicolumn{3}{|c|}{ EMF values, $\mathrm{mV} \approx$} & \\
\hline \multirow{2}{*}{ Fluke } & 800 & 87 & 67 & 238 & 392 \\
\hline & 1500 & 20 & 12 & 193 & 225 \\
\hline \multirow{2}{*}{ V1net } & 800 & 37 & 90 & 238 & 365 \\
\hline & 1500 & 24 & 13 & 191 & 229 \\
\hline
\end{tabular}

According to the obtained research results, the following can be stated. In the measured chain "cylinder liner - engine block - crankshaft - current collector" in the mode of crankshaft rotation speed of $800 \mathrm{rpm}$, the total EMF value is $382-392 \mathrm{mV}$, in the measured chain "piston - cylinder liner" - $37-87 \mathrm{mV}$, and in the measuring chain "cylinder liner engine block" - $67-106 \mathrm{mV}$, in the measured chain of the engine crank mechanism - 200 $238 \mathrm{mV}$ (tables 1 - 4).

The measurements carried out in the second mode, corresponding to the engine speed of $1500 \mathrm{rpm}$, show that the highest total EMF value is observed in the measured chain "cylinder liner - engine block - crankshaft - current collector", the value of which is 225 $392 \mathrm{mV}$. The smallest value of the total value of the EMF - $20-59 \mathrm{mV}$ is observed in the measured chain "piston - cylinder liner". In the chain "cylinder liner - ICE block" the total value of the EMF was $12-90 \mathrm{mV}$, and in the chains of the crank mechanism - $190-196$ $\mathrm{mV}$ (Tables 5 - 8).

Analyzing the data in tables $1-8$, one can see that with an increase in the rotational speed, the value of the EMF arising in couplings of the engine friction pairs decreases. These data do not contradict the previously obtained theoretical calculations.

To confirm the dependence of the EMF on the clearance size in the measured friction pairs of the engine, micrometry of the engine couplings was carried out. The measurement of real clearances in the measured friction units was carried out with the disassembly of the engine after carrying out studies to determine the magnitude of the emerging EMF. The results of the correspondence between the real clearances in the engine friction pairs and the corresponding EMF values are summarized in Table 9.

Table 9. Values of the EMF magnitude by clearance parameters in friction pairs of the engine.

\begin{tabular}{|c|c|c|c|c|}
\hline \multirow{2}{*}{$\begin{array}{c}\text { Name of the } \\
\text { parameter }\end{array}$} & $\begin{array}{c}\text { Cylinder liner - } \\
\text { piston }\end{array}$ & $\begin{array}{c}\text { Piston pin } \\
\text { bushing - piston } \\
\text { pin }\end{array}$ & $\begin{array}{c}\text { Connecting rod } \\
\text { inserts -connecting } \\
\text { rod journal }\end{array}$ & $\begin{array}{c}\text { Main bearing- } \\
\text { main bearing } \\
\text { journal }\end{array}$ \\
\hline $\begin{array}{c}\text { Clearance size } \\
\text { according to } \\
\text { micrometry, mm. }\end{array}$ & 0,10 & 0,172 & 0,088 & 0,092 \\
\hline $\begin{array}{c}\text { EMF value, mV } \\
\text { theoretical } \\
\text { in the study }\end{array}$ & 86 & 212 & 212 & 212 \\
\cline { 2 - 5 } & 87 & 238 & 238 & 238 \\
\hline
\end{tabular}

Analyzing the data obtained, we can be see that the match between the previously calculated theoretical and experimentally obtained values of the EMF magnitude and the 
clearance between the rubbing surfaces of the engine couplings for the couplings of the cylinder-piston group is $1 \%$. For the crank gear couplings this value is $15.1 \%$. This value can be explained by the fact that it is difficult to distinguish one rubbing pair in the crank gear. However, this problem can be resolved with further studies.

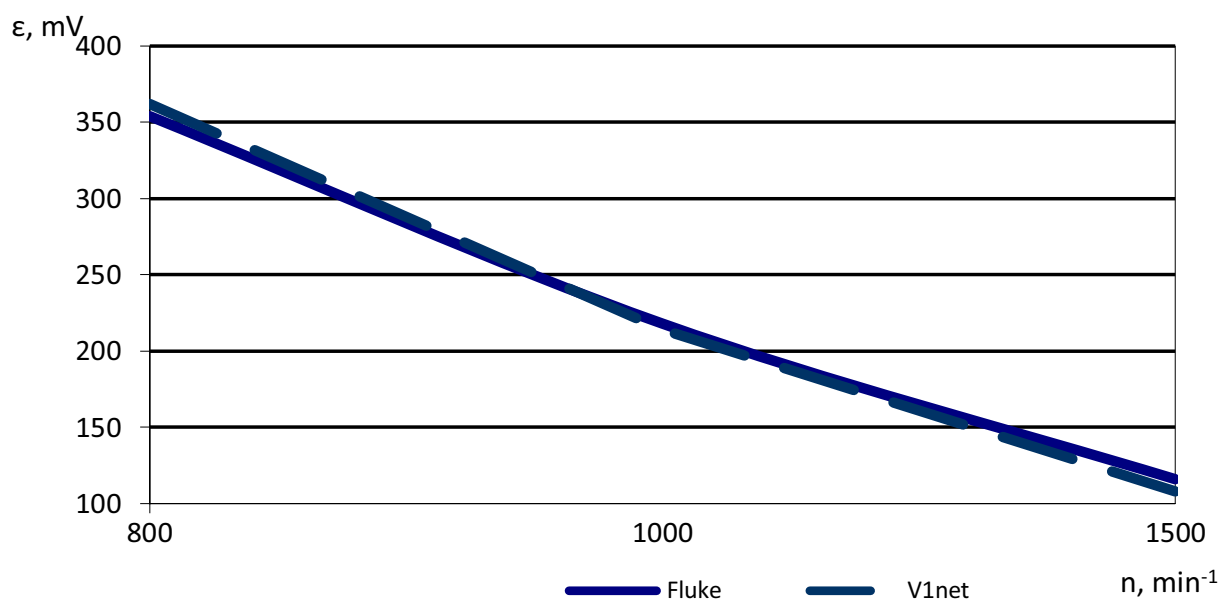

Fig. 9. Change in the value of EMF $(\varepsilon)$ depending on the speed of the engine crankshaft.

\section{Conclusion}

The conducted studies of measurements of the EMF magnitude that arises in couplings of a commercially available engine showed rather high convergence of theoretical and experimental values of the EMF magnitude. Based on this, it can be concluded that the proposed technique for technical diagnostics of power machines, as well as other units of transport and traction machines, can be used for production purposes.

\section{References}

1. A. A. Zamaidinov, A. K. Subaeva, M. I Subaev, I. R Salakhutdinov, Astra Salvensis, 5(10 S1), 505-511 (2017)

2. A. K. Subaeva, A. A. Zamaidinov, M. I. Subaev, I. R. Salakhutdinov, J. Fundam. Appl. Sci., 9 (1S), 1964-1973 (2017)

3. A. K. Subaeva, A. A. Zamaidinov, M. I. Subaev, I. R. Salakhutdinov, J. Fundam. Appl. Sci., 9 (1S), 1956-1963 (2017)

4. D. A. Ukhanov, A. P. Ukhanov, V. A. Perov, Vestnik of Ulyanovsk State Agricultural Academy, 1 (41), 21-25 (2018) doi:8286/1816-4501-2018-1-21-25.

5. A. Khokhlov, A. Khokhlov, D. Marin, D. Molochnikov, I. Gayaziev, In Proceedings of International Scientific-Practical Conference "Agriculture and Food Security: Technology, Innovation, Markets, Human Resources" (FIES 2019), 00077 (2020), doi: 10.1051/bioconf/20201700077.

6. A. Glushchenko, D. Molochnikov, A. Khokhlov, E. Proshkin, I. Gayaziev, International Scientific-Practical Conference "Agriculture and Food Security: Technology, Innovation, Markets, Human Resources" (FIES 2019), 00018 (2020), doi: 10.1051/bioconf/20201700018. 
7. A. Glushchenko, A. Khokhlov, D. Molochnikov, A. Husainov, E. Proshkin, I. Gayaziev, IOP Conf. Ser.: Earth Environ. Sci., 403(1), 012099 (2019), doi: 10.1088/1755-1315/403/1/012098.

8. A. Glushchenko, A. Khokhlov, D. Molochnikov, I. Salakhutdinov, E. Proshkin, I. Gayaziev, IOP Conf. Ser.: Earth Environ. Sci., 403(1), 012098 (2019), doi: 10.1088/1755-1315/403/1/012098.

9. A. V. Morozov, G. D. Fedotov, N.I. Shamukov, Vestnik of Ulyanovsk State Agricultural Academy, 4 (44), 39-44 (2018), doi:10.18286/1816-4501-2018-4-39-44

10. D. M. Maryin, I. R. Salakhutdinov, D. E. Molochnikov, R. N. Musyakimov, I. I. Gayaziev, Vestnik of Kazan State Agrarian University, 14, № 4-2(56), 64-68 (2019)

11. A. A. Glushchenko, D. E. Molochnikov, S. A. Yakovlev, I. N. Gayaziev, Vestnik of Kazan State Agrarian University, 3 (50), 81-84 (2018)

12. D. Molochnikov, R. Khalimov, I. Gayaziev, D. Rudoy, A. Olshevskaya, E3S Web Conf., 08006 (2020), doi: 10.1088/1755-1315/403/1/012014.

13. A. V. Morozov, G. D. Fedotov, D. R. Musharapov, Vestnik of Ulyanovsk State Agricultural Academy, 2 (46), 19-23 (2019), doi:10.18286/1816-4501-2019-2-19-23.

14. V.I. Dolgov, V. I. Kurdyumov, A. A. Pavlushin, Vestnik of Ulyanovsk State Agricultural Academy, 1(41), 6 - 10 (2018), doi:10.18286/1816-4501-2018-1-6-10.

15. V. I. Kurdyumov, E.S. Zykin, V. E. Gavrilova, Vestnik of Ulyanovsk State Agricultural Academy, 2 (42), 13 - 17 (2018), doi:10.18286/1816-4501-2018-2-13-17.

16. Yu. M. Isaev, N. M. Semashkin, S. A. Kalenkov, Vestnik of Ulyanovsk State Agricultural Academy, 3 (43), 6 - 11 (2018), doi:10.18286/1816-4501-2018-3-6-11. 